\title{
Teaching Oral Consecutive Interpretation
}

\author{
Roza Ayupova (Corresponding author) \\ Kazan Federal University Russian Federation \\ E-mail: roza.ayupova.00@mail.ru
}

Received: 13-08-2016

Published: 10-12-2016
Accepted: 17-10-2016

doi:10.7575/aiac.ijalel.v.5n.7p.163
Advance Access Published: November 2016

URL: http://dx.doi.org/10.7575/aiac.ijalel.v.5n.7p.163

\begin{abstract}
The paper describes the research conducted in interpreter-training based on the experience of teaching oral consecutive interpretation in two groups of undergraduate students approximately of the same level of linguistic and translation skills. In one of the groups - key informants - metacognitive approach was applied to have the would-be interpreters conscious of what they are expected to be successful interpreters. As many scholars in this field claim, metacognitive competence developed in the process of education is believed to form the ability to meet the challenges an interpreter can face executing oral consecutive interpretation. Since attentiveness and memory are viewed as important mechanisms of psychological base of the type of interpretation under consideration, special sets of exercises directed to developing these properties in interpreters-to be elaborated by contemporary scholars according to special methodology were given in this group. The next group - focus group - was also provided with the same educational technologies and other facilities as the group of key informants, but metacognitive approach and aforementioned sets of exercises were not used in it. Long-term memory tests held at the beginning and at the end of the semester in both the groups demonstrate that metacognitive approach in combination with special sets of exercises lead to much better results in long-term memory developing.
\end{abstract}

Keywords: interpreter-training, oral consecutive interpretation, metacognitive approach, psychological base, long-term memory, learning curve

\section{Introduction}

Increased competition in labour-market, active scientific and business collaborations between companies of different countries require high level of competence of specialists in translation nearly in any field of human activity. Therefore researches into methodology of translator and interpreter-training are becoming more and more up-to date. Consecutive interpretation being one of the most widely used types of translation attracts the attention of many scholars; however a number of issues still remaining in the field evidence for the timeliness of the suggested research. The main objective of the current paper is to distinguish the major tasks of consecutive interpreter training and quest for effective ways of solving them. The research is based on the experience of consecutive interpreter training classes with undergraduate students in the Institute of Philology and Intercultural Communication of Kazan federal University. In two groups of approximately the same level the work in classes of oral consecutive translation was organized differently and the learning curve of the students was checked and registered at the beginning and at the end of the course. And the results were compared.

Achieving the main goal requires delving into the essence of translation itself, which is known as a process of transforming a text in the source language into one in the target language. Viewing from this angle an interpreter should have excellent linguistic competences in both the languages.

Translation is proved intercultural mediated communication, so a would-be translator should acquire deep knowledge in the culture and history of the people speaking both (foreign and native) languages. Moreover, translation / interpretation process demands being informed about various spheres. The whole of interpreter-training program should be based on awareness of the fact that translation presupposes equivalence to meaning and sense of separate linguistic units, to the message of the whole discourse, and to formal characteristics of the text (Čeňková, 1998). So permanent adding up of cultural encyclopedic information from as many fields as possible is seen as integral part of translation process.

As it was mentioned above equivalence is one of the essential requirements of translation. E. Nida (Nida, 2001 p.104) points out that "concepts are the units that form the basis for finding equivalent expressions in the receptor language. "The notion of 'concept' is used by Jorge Luis Rodríguez Morell in his work "Toward the development of a metacognitive intercultural communicative competence in the education of students of interpreting: general theoretical/ pragmatic foundation" as a basic analytic unit for information processing. The super-objective of interpreter-training process, to the opinion of this scholar, is development of "metacognitive intercultural communicative competence - a complex, integrating, psychological, socio-linguo-cognitive and communicative construction as well as a mode of action that can only be developed first of all in-class focusing on the attempted "visualization" of the interpreter's mental process during the phases of comprehension, reformulation and re-expression of the message to be rendered" (Morell, 2011). 


\section{Main text}

\subsection{Methods}

Almost all authors (V. Komissarov, 1990; E. Nida, 2001; E. Breus, 2000; D. Danilchenko, 2010 etc.) in translation admit the fact of translation /interpretation process being inter-linguistic, therefore translation problems are discussed at any level of the language: lexical, phraseological, structural, contextual.

A review of the works on translation theory and interpreter-training methodology suggests that nearly all scholars recognize translation not only as inter-linguistic, but as intercultural communication in which at least two languages are involved (Hymes, 1972; Morell, 2011 etc.). In accord to this developing intercultural communicative competence is seen through linguistic competence, sociolinguistic competence, pragmatic or discourse competence and strategic competence (J. Morell, 2011).

Sociolinguistic approach to interpretation, as one of the up-to-date views on it, mostly studies the relations: society interpretation and individual - interpretation. These papers are: "Organizatsia protsessa obuchenia ustnomu posledovatelnomu perevodu v svete sinergeticheskoy teorii" by S. Gural, E. Tikhonova (Gural \& Tikhonova, 2013), "Issues of Translation Research in the Inferential Paradigm of Communication" by E. Gutt (Gutt, 2000) etc. consider the society as the environment for realization of the language, communication and interpretation; individual - as a means of refracting the language when using it. Any text intended be translated is marked by some traits of individual personal culture of its original sender, which are to be identified and retained in translation. At the same time a translator-to be should be taught to remain objective and impartial to what $\mathrm{s} / \mathrm{he}$ is translating. Pretranslation text analysis is offered as the way to identify national, ethnic, social and individual markers in a source text and decide how each of them should be retained in translation (Ayupova 2014).

Translation process deals with bilingual discourses. As one of their basic categories S. Gural and E. Tikhonova (Gural \& Tikhonova, 2013) distinguish implicature - part of the meaning expressed implicitly whose comprehension requires some intellectual abilities. Accordingly this aspect of translation is also to be given necessary attention by interpretertraining educational programs. Problems of comprehending the two layers of information - explicature and implicature are also discussed by Sperber and Wilson in their work "Relevance: Communication and Cognition" (Sperber \& Wilson, 1986). The authors tie this problem with abilities and intentions of an individual in language use.

In Salma Haddad's paper "Training Interpreters: No Easy Task" educational process is represented as "gradual confidence-building strategies to improve the students' interpretation skills" (Haddad, 2008 p. 34). The process is divided into three phases, the Warm-Up Phase; the Intermediate Phase; the Advanced Phase. Consecutive interpretation as such is included by the author into the second phase as the second stage of study following after liaison interpreting.

Oral consecutive interpretation has become the focus of attention of quite many works; the authors study this type of translation / interpretation as a complex psychological activity of human mind (Sdobnikov, 2006; Alikina, 2012; Baddeley, 2003 etc.). Accordingly, this type of interpretation consists of various aspects, each of them are given special attention of scholars.

J. Morell describes the interpreter's activity in three basic stages: "comprehension of the intended meaning and discourse in the source language and cultural polysystem, reformulation (in fact, an invisible mental process, extremely difficult to make visual before students in class, at least in the undergraduate teaching-learning process) and reexpression, or the always somewhat synthesized, (for time and memory saving purposes) re-utterance of the core information in the target language and cultural polysystem, aimed at being satisfactorily understood by the audiences the interpreter addresses" (Morell, 2011 p.108). When referred to oral consecutive interpretation the first stage comprehension - will be aural perception of the original text which requires special linguistic competence. Reformulation stage is characterized by its own specificities related to the necessity of remembering each chunk of the source language text. Difficulties of the stage of re-utterance or re-expression are connected with the time limit and oral character of interpretation. Consequently, interpreter-training process is directed to solving all the problems arising on each of the three stages of oral consecutive translation.

In the current paper we try to consider the results of the researches mentioned above and apply the following methods: observation methods (as controlled, so natural ones) - to observe the learning curves of the students in the classes of oral consecutive translation; descriptive method - describe linguistic and communicative competences development in the students; statistic methods to register the results of the process of developing necessary competences.

\subsection{Metacognition in learning interpretation. Developing attentiveness in interpreter-training classes}

The importance of visualizing all the cognitive processes, taking place in the mind of an interpreter very often in a matter of seconds, during oral consecutive interpretation was already mentioned. For this at the very first class we demonstrate the process of interpretation involving the languages active in the groups making up the informants of the research. After which the group analyze the demonstrated interpretation process highlighting the competences necessary for an interpreter. Some essential theoretical knowledge about oral consecutive interpretation is communicated to the students in lecture classes, though their number is very limited. Doing so a teacher will provide the students' consciousness of what they are expected at the end of the course and the all the mental operations they perform could be self-reflective and self-controlling.

Metacognitive competence in interpreter-training process was described by theoreticians (J. Morell, 2011; Ch. Jung, 2006) as one of the important preconditions of success. "Metacognition in learning can be described as the awareness 
of the learning process and the ability to adapt to challenges that occur during this process through effective strategies, thereby helping learners improve their learning capacity" (Jung, 2006 p.278).

The first competence pointed out by the students (sometimes with the help of the teacher) is listening and comprehension. No doubt that the work on developing this competence has been started from the first days of their study in the faculty of foreign philology, but the work should be unceasing, as the type of translation under consideration demands high level of competences. Listening for oral consecutive interpretation is an intelligent listening process, because an interpreter is not only to comprehend what $\mathrm{s} / \mathrm{he}$ has heard, but also to process the information and differentiate the core information from the secondary part, which could add some complementary details. One should admit that this is a complicated activity for which an interpreter must be prepared purposefully. The most responsible part of interpreter's activity is re-expressing the core information retained in her /his mind in the target language. Therefore listening process here is bound to one ability or quality - attentiveness, better to say remaining attentive during all period of work, listening. Leaving even one word may result in failure of understanding the core information.

Eliciting psychological base of interpretation is one of the most important premises of realizing the essence of interpretation (Sdobnikov, 2006) V.Sdobnikov singles out the following the most active psychological mechanisms of oral consecutive interpretation: attentiveness, perception, probabilistic forecasting, memory and thought (Morell 2008). So in our classes we try to develop all the necessary skills and competences of our students, but in this paper we describe our work on developing their attentiveness and long-term memory.

One of the preconditions leading to high degree of attentiveness is appropriately organized exercises. I.Alekseeva (Alekseeva, 2001) suggests that they should consist of short texts of 160 - 170 words on various topics. As the author claims, working with long texts on the same topic makes the process of work monotonous, which in its turn leads to weakened attentiveness. Considering this, in the group of key informants we gave exercises with short texts (160 - 170 words) on different topics: medicine, sport, business, economics, politics, culture, travelling, nutrition etc. In the other group, we called it focus group, the exercise for the whole class consisted of only one text (naturally on one and the same topic).

One more piece of advice from the distinguished scholar I.Alekseeva for developing attentiveness of interpreters-to be is systematically altering the direction of interpretation: native > foreign, foreign > native. Following this recommendation students were asked to interpret from English into Russian, from Russian into English and so on. These exercises also work as a means of developing the ability of an interpreter-to be to refocus her / his attention.

Even during the class one could observe that at the beginning of each text, which was not only on a different topic, but also in a different language than the previous one, students demonstrated higher level of attentiveness, which could be seen from their facial expression, look when listening; and more accurate interpretation at the beginning of each text than at their end. However, assessing the ability of a student to remain attentive can be only done together with assessing the volume of his memory, because it is attentiveness that enables her / him to keep in the mind larger chunks of a text with more details.

\subsection{Developing long-term memory}

Bilingual consecutive interpretation as one of the oral variants of translation is based on an intensive work of memory. When working with small chunks of speech consecutive interpreter uses mid-term memory, as usual it is interpretation of close interaction of interlocutors. In general oral consecutive interpreter resorts to use long-term memory when storage of information takes place on a newly created neural pathway, that's why this information can be accessible in weeks or even years later (Zhong, 2001). For this quality of it, long-term memory is used in learning process.

The necessity of long-term memory use in consecutive interpretation is accounted for some circumstances under which this type of interpretation occurs. Usually it is official texts communicating complex idea expressed in long compound sentences that are interpreted. Therefore it is inconvenient to interrupt the speech until a unit of idea or at least a part of it is not expressed. Then it is not permissible from aesthetic viewpoint to interrupt a speech before the utterance is completed. Thus it is vitally important for an interpreter to have highly developed mid-term and long-term memory.

Following recommendations of S. Haddad, we organize interpreter-training classes in the key informants group dividing them into two stages: stage I "deals with liaison interpreting”, stage II - consecutive interpretation. In stage I students are given interviews where contributions of each interlocutor are recorded in both the languages - English and Russian. The work of this stage is aimed at training mid-term memory, because interviews with quite short utterances are selected here. In stage II would-be interpreters are first provided with the first variant of the text, which is recorded in short segments; then - with the second variant of the same text, recorded in longer segments. The text is accompanied by its translation that is listened to by the students for checking the quality of their translation (Haddad, 2008).

S. Haddad suggests that the memory-training phase should precede even the warm-up phase, unfortunately, the limited number of classes given to consecutive interpretation in our educational program do not allow us to have a separate phase for it. So we decided to do memory-training exercises at the beginning of each class. These exercises are done in four steps: in step I, texts are provided in the mother tongue, after listening to which students try to recall them in the same language with as many details as possible; in step II the same work is done with texts in the foreign language; in step III, students are expected to listen to English texts and to recall as much as they can in the native language; in step IV the suggested texts are in the native language which are to be recalled in the foreign language (Haddad, 2008). 
At the first class of oral consecutive interpretation long-term memory of students was checked as in the group of key informants so in the focus group. Each interpreter-to be listened to a chain of words consisting of 35 units. When asked to recall what they have listened to they showed the following results:

Table 1. Long-term memory check at the beginning of the semester

\begin{tabular}{llll}
\hline Key informants group & Number of words remembered & Focus group \\
\hline Students & & Students & $\begin{array}{l}\text { Number of } \\
\text { words } \\
\text { remembered }\end{array}$ \\
\hline A & 7 & A & 9 \\
\hline B & 6 & B & 5 \\
\hline C & 7 & C & 5 \\
\hline D & 10 & D & 8 \\
\hline E & 8 & E & 6 \\
\hline F & 8 & F & 10 \\
\hline G & 7 & G & 9 \\
\hline H & 10 & H & 7 \\
\hline I & 8 & I & 7 \\
\hline J & 9 & J & 9 \\
\hline
\end{tabular}

The same test at the end of the semester when the classes of oral consecutive interpretation were coming to their end demonstrated the following results.

Table 2. Long-term memory check at the end of the semester

\begin{tabular}{llll}
\hline Key informants group & Number of words remembered & Focus group \\
\hline Students & & Students & $\begin{array}{l}\text { Number of } \\
\text { words } \\
\text { remembered }\end{array}$ \\
\hline A & 12 & A & 12 \\
\hline B & 10 & B & 7 \\
\hline C & 12 & C & 8 \\
\hline D & 16 & D & 10 \\
\hline E & 14 & E & 9 \\
\hline F & 15 & F & 13 \\
\hline H & 13 & G & 13 \\
\hline I & 17 & H & 10 \\
\hline J & 15 & I & 10 \\
\hline
\end{tabular}

\section{Conclusions}

The review of theoretical works on consecutive interpretation witnesses that as one of the most complicated types of interpretation it is a complex psychological activity. As the major tasks of oral consecutive interpreter training we distinguish the following: developing attentiveness (ability to refocus and disperse the attention), the ability to comprehend and to process the received information, the ability to retain the information in the mind (mid-term, longterm memory), note taking skills, the ability to select appropriate lexical units and structures in the target language.

The current paper is aimed at revealing the process of work on developing attentiveness and long-term memory of would-be oral consecutive interpreters. The research was conducted on the experience of work with two groups of students: a group of key informants and a focus group.

Metacognitive approach applied to the first group proved to be effective due to self-controlling and self-reflecting aroused in the group at the very beginning of the course. Juxtaposition of the learning curve of the students in both the groups at the beginning and at the end of the courses demonstrate that in the first group, where metacognitive approach was applied, the worst result was improved by $66,6 \%(6>10)$ while as in the second group this improvement is $40 \%(5$ 
$>7)$; improvement of the best result in the first group is improved by $87 \%(10>17)$, in the second group the improvement of the best result is $30 \%(10>13)$.

However the success of the group of key informants cannot be attributed only to applying metacognitive approach. We think that mostly the use of special exercises directed to heightening attentiveness of would-be interpreters and developing their long-term memory played much bigger role in achieving the success.

\section{References}

Alekseeva I. S. (2001). Professionalny trening perevodchika: Uchebnoe posobie po ustnomu i pismennomu perevodu dlya perevodchikov i prepodavateley. S.-Petersburg: Publishing House "Soyuz".

Alikina, E. (2012). Psikhologicheskaya model ustnogo posledovatelnogo perevoda. Pedagogicheskie nauki, 6(1), 124132.

Ayupova, R. (2014). Pretranslation text analysis as a part of translation process. Social and Behavioral Sciences, 3(1), 213-216.

Baddeley, A. D., Thomson, N, \& Buchanan, M. (1975). Word length and the structure of short-term memory. Journal of Verbal Learning and Verbal Behavior, 14, 575-589.

Breus, E.V. (2000). Osnovy teorii i praktiki perevoda s russkogo yazyka na angliiskii: Textbook. 2nd edition. Moscow: Publishing House URAO.

Čeňková, Ivana (1998). Quality of Interpreting - a Binding or a Liberating Factor? In Ann Beylard-Ozeroff, Jana Králová Barbara \& Moser-Mercer (Eds.) Translators' Strategies and Creativity (pp.163-170). Amsterdam and Philadelphia: John Benjamins.

Danilchenko, D. (2010). K voprosu o kachestve ustnogo posledovatelnogo perevoda i parametrah ego otsenivania. Vestnik Khmelnitskogo Natsionalnogo Universiteta, 896(1), 169-175.

Gural, S. and Tikhonova, E. (2013). Organizatsia protsessa obuchenia ustnomu posledovatelnomu perevodu v svete sinergeticheskoy teorii. Yazyk i kultura. 4(24), 77-82.

Gutt, E. (2000). Issues of Translation Research in the Inferential Paradigm of Communication. In Maeve Olohan (Ed.) Intercultural Faultiness: Research Models in Translation Studies I - Textual and Cognitive Aspects (pp.161-180). Manchester: St. Jerome.

Haddad, S. (2008). Training Interpreters: No Easy Task. Damascus University Journal, 24(1-2), 31-46.

Hymes, D. H. (1972). On communicative competence. In Pride, J.B. and Holmes, J. (Eds.) (First published in 1971). Sociolinguistics: Selected readings (pp. 269-293). Harmondsworth: Penguin.

Jung Yoon Choi. (2006). Metacognitive Evaluation Method in Consecutive Interpretation for Novice Learners. Translators' Journal, 51(2), 273-283.

Komissarov, V. N. (1990). Teoriya Perevoda (lingvisticheskie aspecty): Textbook for students of faculties of foreign languages. Moskow: Vysshaya shkola.

Morell, R. (2008). How to improve professional memory in bilingual consecutive interpreting. [Online] Available: file:///C:/Users/LENOVO/Downloads/how-to-improve-professional-memory-in-bilingual-consecutive-interpreting$1 \% 20(2)$.pdf.

Morell, R. (2011). Toward the development of a metacognitive intercultural communicative competence in the education of students of interpreting: general theoretical/ pragmatic foundation. International Journal for Translation \& Interpreting Research. 3(1), 106-118.

Nida, Eugene A. (2001). Contexts in Translating. Amsterdam and Philadelphia: John Benjamins.

Sdobnikov, V. \& Petrova, O. (2006). Teoriya perevoda: Uchebnik dlya studentov lingvisticheskih vuzov i fakultetov inostrannyh yazykov. Moscow: AST: Vostok-Zapad.

Sperber, D. \& Wilson, D. (1986). Relevance: Communication and Cognition. Oxford: Basil Blackwell.

Zhong, W. (2001). Simultaneous Interpreting: Principles and Training. China Translators' Journal, 22, 39-43. 